Check for updates

Cite this: RSC Adv., 2017, 7, 54813

Received 11th August 2017

Accepted 6th November 2017

DOI: 10.1039/c7ra08903a

rsc.li/rsc-advances

\section{Magnetic nanoparticles as double-edged swords: concentration-dependent ordering or disordering effects on lysozyme}

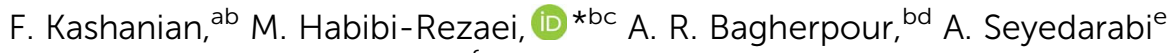 \\ and A. A. Moosavi-Movahedi ${ }^{\text {ef }}$
}

The study of the interaction of nanoparticles (NPs) with proteins is of great importance due to its relevance in several fields including nano-biosafety, nano-bioscience, nano-biomedicine, and nanobiotechnology. However, the concentration dependency of NP-protein interactions and the effects on protein structure and function remain to be explored. Herein, we report the effect of concentration of iron oxide NPs, including $\mathrm{Fe}_{3} \mathrm{O}_{4}$ and $\mathrm{Fe}_{3} \mathrm{O}_{4}$ incorporated with arginine $\left(\mathrm{Fe}_{3} \mathrm{O}_{4} \mathrm{Q} \mathrm{Arg}\right.$ ), on the stability of hen egg white lysozyme (HEWL) (EC 3.2.1.1) used as a model protein. The NPs were synthesized and characterized using various methods, including Fourier transform infrared (FT-IR), transmission electron microscopy (TEM), scanning electron microscopy (SEM), vibrating sample magnetometer (VSM), dynamic light scattering (DLS), and X-ray diffraction (XRD). Subsequently, an attempt was made to explore the influence of the two types of NPs on the structure and stability of HEWL using fluorescence and circular dichroism (CD) spectroscopies. Moreover, functional stability analysis was performed by monitoring the remaining enzymatic activity of HEWL. Dual concentration dependent (DCD) effect of NPs on HEWL was observed, in which concentration threshold shift between two opposing effects, that is structure-making and structure-breaking, were determined to be $12.86 \mathrm{mg}$ per $\mu \mathrm{mol}$ protein and $3.6 \mathrm{mg}$ per $\mu \mathrm{mol}$ protein for $\mathrm{Fe}_{3} \mathrm{O}_{4}$ and $\mathrm{Fe}_{3} \mathrm{O}_{4}$ @Arg, respectively. Kosmotropic-like and inversely chaotropic-like effects of NPs on HEWL are reported at lower and higher NPs/protein ratios, respectively. Accordingly, protein folding, helicity, and half-life were improved at a low concentration of NPs. The NPs act on HEWL structure and stability presumably through electrostatic adsorption on NPs, which, in turn, influences the structure and dynamics of the hydration water shell surrounding the protein molecules in the aqueous solution of HEWL. Therefore, NPs can act on HEWL either as a friend or foe depending on their concentration.

\section{Introduction}

Nowadays, along with the development of applications of nanoparticles (NPs) in various fields of medicine, industry, and pharmaceutics, in particular, studies of the interaction between NPs and proteins have become essential (at the molecular level revealing biological implications) from a nano-biosafety point of view. NPs possess distinct physical and chemical properties when compared with the bulk form of similar materials as the

\footnotetext{
${ }^{a}$ Department of Life Science Engineering, Faculty of New Sciences and Technologies, University of Tehran, Tehran, Iran

${ }^{b}$ School of Biology, College of Science, University of Tehran, Tehran, Iran. E-mail: mhabibi@ut.ac.ir; Fax: +98-21-66971941; Tel: +98-21-2-61113214

${ }^{c}$ Nano-Biomedicine Center of Excellence, Nanoscience and Nanotechnology Research Center, University of Tehran, Tehran, Iran

${ }^{d}$ School of Metallurgy and Materials Engineering, College of Engineering, University of Tehran, Tehran, Iran

${ }^{e}$ Institute of Biochemistry and Biophysics, University of Tehran, Tehran, Iran ${ }^{f}$ Center of Excellence in Biothermodynamics, University of Tehran, Tehran, Iran
}

former exhibit a large surface to volume ratio and a huge Gibb's free energy is detectable, providing NPs with great potential to interact with biological molecules., ${ }^{1,2}$ Therefore, the ability of NPs to influence protein structure is of great importance not only because of the potential beneficial applications but also the potential risks to human health and the environment. ${ }^{3}$ This makes it essential to understand the effect of NPs specifically on protein stability. Proteins acquire functional structures due to well-organized interactions with surrounding water molecules. Protein unfolding occurs when the balance of forces between the protein-protein interactions and the protein-solvent interactions are disrupted because of the perturbation of the water structure and dynamics around the protein. ${ }^{4-8}$ It is assumed that the protein-NPs interactions could impact protein hydration which is an important issue to consider for understanding the stability, dynamics, and functioning of proteins in aqueous solutions. Therefore, among the three categories of water molecules in the vicinity of proteins, i.e., internal, hydration and bulk water molecules, 
the water molecules specifically in the water-protein interface acting as hydration layers have the most influence on protein structure and function. ${ }^{9-11}$ Chaotropic co-solvents perturb the water structure and dynamics around the protein more significantly. Internal and hydration water molecules cause the disruption of protein stabilizing interactions and consequently the protein function. These water molecules destabilize both the native structures and the hydrophobically aggregated structures through increasing the solubility of hydrophobes or exposing hydrophobic residues through inclusion in the water-protein interfaces, which encourage protein denaturation and disaggregation, respectively. ${ }^{4-8}$ Conversely, kosmotropic co-solvents are highly soluble and can be hydrated through strong hydrogen bonds with water molecules and preferentially excluded from protein-solvent interfaces. As a result, they stabilize both folded and unfolded protein structures through burial of hydrophobic residues to keep them ordered as stabilized native structures or enhance hydrophobic aggregation of misfolded species, respectively. ${ }^{12}$ Therefore, an influential protein stabilization strategy is the application of a broad category of kosmotropic co-solvent molecules, such as arginine (Arg). ${ }^{13,14}$ However, both kosmotropic $^{15}$ and chaotropic effects ${ }^{14}$ have been reported for Arg, therefore different physico-chemical properties are expected depending on the chemical nature of NPs, which could have different effects on protein structure and function. ${ }^{1,16}$ For example, a potential safety hazard of NPs with a hydrophobic surface, which can lead to negative effects on proteins, is relieved through surface functionalization with hydrophilic groups. ${ }^{17}$ NPs are synthesized in various sizes, which determine their surface curvature; larger NPs have smaller surface curvature and thus a greater surface for contact with adsorbed proteins, resulting in stronger interactions between proteins and NPs. Therefore, the size of NPs could be a crucial factor affecting the interaction of NPs with proteins and consequently their stability due to its small size and high surface area-to-volume ratio. The interaction of proteins with NPs in solution could be affected by several thermodynamic parameters. ${ }^{1,18}$ As such, designing the surface chemistry of NPs is the most effective approach to manipulating the protein-NP interactions to improve, for example, their biocompatibility. ${ }^{17}$ Accordingly, NPs with biocompatible coatings are the only nano-structural materials that have been approved by the FDA for clinical use. ${ }^{19}$

Magnetic $\left(\mathrm{Fe}_{3} \mathrm{O}_{4}\right)$ NPs have attracted intensive interest for a wide range of applications, including magnetic fluids and immobilization of proteins, peptides, and enzymes. ${ }^{20,21}$ Moreover, incorporation of the amino acid $\mathrm{Arg}$ in $\mathrm{Fe}_{3} \mathrm{O}_{4}\left(\mathrm{Fe}_{3} \mathrm{O}_{4} @ A r g\right)$ has proven to be efficient in terms of biocompatibility and nontoxicity ${ }_{1}^{19}$ Herein, we report the effect of $\mathrm{Fe}_{3} \mathrm{O}_{4}$ and $\mathrm{Fe}_{3} \mathrm{O}_{4}$ @Arg NPs on hen egg white lysozyme (HEWL) (EC 3.2.1.1) as a model protein to elucidate the concentration dependent effect of NPs on HEWL's structure and stability. HEWL is a well characterized single subunit glycoprotein consisting of 129 residues with a molecular weight of $14.3 \mathrm{kDa} .^{22}$ The results of this study have shed light on the kosmotropic-like or chaotropic-like effects of the two mentioned NPs on HEWL.

\section{Materials and methods}

\section{Materials}

HEWL with a molecular weight of $14.3 \mathrm{kDa}$ and 9,10-phenanthrenequinone were obtained from Sigma-Aldrich. All other chemicals, including organic solvents, were acquired from Merck (Darmstadt, Germany) unless otherwise stated. Dried bacterial cell wall from Gram-positive Micrococcus luteus ( $M$. luteus) was prepared and used as the substrate for HEWL as described by Liu et $a .^{23}$

\section{Synthesis and characterization of $\mathrm{Fe}_{3} \mathrm{O}_{4}$ and $\mathrm{Fe}_{3} \mathrm{O}_{4} @ A r g$ NPs}

NPs were prepared by the well-known Massart's method which consists of $\mathrm{Fe}(\mathrm{III})$ and $\mathrm{Fe}(\mathrm{II})$ co-precipitation in alkaline solutions. $^{24}$ To achieve a stoichiometric ratio of $2 \mathrm{Fe}^{3+}: \mathrm{Fe}^{2+}$, $16 \mathrm{mmol} \mathrm{FeCl}_{3} \cdot 6 \mathrm{H}_{2} \mathrm{O}$ and $8 \mathrm{mmol}$ of $\mathrm{FeCl}_{2} \cdot 4 \mathrm{H}_{2} \mathrm{O}$ were dissolved in $190 \mathrm{~mL}$ of deionized water at room temperature by magnetic stirring under $\mathrm{N}_{2}$ stream. Subsequently, $10 \mathrm{~mL}$ of $25 \% \mathrm{NH}_{3}$ was added to the iron solution, under vigorous stirring. Immediately, magnetite formed a black precipitate. After stirring for ten minutes, the particles were washed thrice with buffer. After each step, NPs were separated with a magnet. ${ }^{25}$ A method was also developed for the synthesis of $\mathrm{Fe}_{3} \mathrm{O}_{4} @ A r g$ NPs: $50 \mathrm{~mL}$ solutions of $\mathrm{FeCl}_{2} \cdot 4 \mathrm{H}_{2} \mathrm{O}$ and $\mathrm{FeCl}_{3} \cdot 6 \mathrm{H}_{2} \mathrm{O}$ at a final concentration of $20 \mathrm{mM}$ and $40 \mathrm{mM}$, respectively, were mixed with an equal volume of $\operatorname{Arg}$ (at $20 \mathrm{mM}$ ) under $\mathrm{N}_{2}$ stream at $15{ }^{\circ} \mathrm{C}$ with vigorous stirring. The synthesized $\mathrm{Fe}_{3} \mathrm{O}_{4} @ A$ arg was then subjected to magnetic separation after $3 \mathrm{~h}$ reaction and washed with deionized water six times. Subsequently, the resulting solid material was washed with ethanol and dried in a vacuum oven at $50{ }^{\circ} \mathrm{C}$ for $24 \mathrm{~h}$.

After synthesis of the NPs, they were characterized using various analytical methods. Fourier transform infrared (FT-IR) spectroscopy was carried out using a Bruker VERTEX 70 model. The NPs were directly observed by transmission electron microscopy (TEM, Philips, FEI Co., USA) and scanning electron microscopy (SEM, KYKY SBC-12). The saturation magnetization of NPs was also characterized by vibrating sample magnetometry (VSM). The zeta potential and size of NPs in double distilled water (DDW, $\mathrm{pH} \leq 7$ ) and phosphate buffer saline (PBS, $100 \mathrm{mM}, \mathrm{pH}=7.4$ ) was estimated using the dynamic light scattering (DLS) instrument from Malvern ZS-Nano series, and X-ray diffraction (XRD) analysis was performed using the Rigaku-Dmax 2500 diffractometer.

The method reported by Nora Graf was applied for the quantification of Arg incorporated on the surface of NPs using the phenanthrene dye, which is a polycyclic aromatic hydrocarbon. ${ }^{26}$ Phenanthrene is almost insoluble in water, but is soluble in most low polarity organic solvents. ${ }^{27}$ 9,10-Phenanthrenequinone has been shown to react with free Arg or with Arg residues within MNPs to produce a compound whose fluorescence can be used to quantify amounts of Arg at sub-microgram level. This dye was mixed with the samples in an alkaline $\mathrm{pH}$ followed by acidification. None of the commonly occurring amino acids or commonly used buffers or organic solvents were found to interfere in this protocol. ${ }^{28}$ 
Structural analysis of the enzyme in the presence of MNPs using spectroscopic methods

A stock solution of HEWL was prepared in $0.1 \mathrm{mM}$ sodium phosphate buffer (pH 7.4) and the enzyme concentration was checked using the extinction coefficient $2.65 \mathrm{dm}^{3} \mathrm{~g}^{-1} \mathrm{~cm}^{-1}$ at a wavelength of $280 \mathrm{~nm} .{ }^{29}$ To study the effect of NPs on HEWL, $5 \mu \mathrm{g} \mathrm{mL}{ }^{-1}$ NPs was incubated with $0.2 \mathrm{mg} \mathrm{mL}^{-1} \mathrm{HEWL}$ for $1 \mathrm{~h}$ at ambient temperature. To observe the concentration effect of NPs on HEWL, $0.2 \mathrm{mg} \mathrm{mL} \mathrm{mLWL}^{-1} \mathrm{HEW}$ incubated in the absence (as control) and in the presence of $\mathrm{Fe}_{3} \mathrm{O}_{4}$ or $\mathrm{Fe}_{3} \mathrm{O}_{4} @ \mathrm{Arg}$ at a corresponding concentration range of $0.001-0.25 \mathrm{mg} \mathrm{mL}^{-1}$ for $60 \mathrm{~min}$. Intrinsic or tryptophan fluorescence intensities of the untreated HEWL as control and HEWL treated with different concentrations of $\mathrm{Fe}_{3} \mathrm{O}_{4}$ or $\mathrm{Fe}_{3} \mathrm{O}_{4}$ @Arg NPs were monitored using a spectrofluorimeter (BioTek, Synergy ${ }^{\mathrm{TM}} \mathrm{H} 4$ hybrid microplate reader) in a quartz plate. The fluorescence emissions of HEWL at $0.2 \mathrm{mg} \mathrm{mL}^{-1}$ in sodium phosphate buffer (0.1 $\mathrm{M}$ and $\mathrm{pH} 7.4)$ were recorded in the wavelength range of $300-400 \mathrm{~nm}$ after excitation at $280 \mathrm{~nm}$ after treatment with NPs at a concentration range of $0.001-0.25 \mathrm{mg} \mathrm{mL}^{-1}$. Both excitation and emission slits were set at $5 \mathrm{~nm}$. The fluorescence emissions of the NPs in the same buffer at the corresponding concentrations were also recorded as blanks.

The far-UV circular dichroism analyses were used to study the alterations in the helicity content of HEWL (at $0.2 \mathrm{mg} \mathrm{mL}^{-1}$ ) in the absence or presence of NPs $\left(0.005 \mathrm{mg} \mathrm{mL}^{-1}\right)$. The circular dichroism (CD) spectroscopies were obtained using the AVIV Circular Dichroism Spectrometer Model 215. The final spectra were corrected using the spectrum from the buffer as a blank. The CD results were expressed as mean residual ellipticity (MRE) in deg $\mathrm{cm}^{2} \mathrm{dmol}^{-1}$. Deconvolution of the CD spectra was achieved using CDNN software (http://bioinformatik.biochemtech.unihalle.de/cd-spec/cdnn) to determine the percentage of different secondary structural elements. All results are the average of at least three trials.

\section{Functional stability analysis}

HEWL activity testing was carried out using a turbidometric assay protocol, in which the lysis rate of M. luteus was determined as reported by Shugar (1952). Accordingly, a unit enzyme activity was defined as a turbidity decrease of 0.001 per minute at $450 \mathrm{~nm}$ in potassium phosphate buffer $(0.1 \mathrm{M}$ and $\mathrm{pH} 7.4$ ) at $25{ }^{\circ} \mathrm{C}$. Briefly, $100 \mu \mathrm{L}$ of the stock solution of HEWL at $0.2 \mathrm{mg} \mathrm{mL}^{-1}$ in sodium phosphate buffer was added to $2.5 \mathrm{~mL}$ of $0.01 \%(\mathrm{w} / \mathrm{v})$ of the $M$. luteus suspension (as substrate) in potassium phosphate buffer and absorbance change per minute at $450 \mathrm{~nm}$ was recorded. To study functional stability, $2 \mathrm{~mL}$ of the stock solution of HEWL was incubated at room temperature in the absence of NPs (as control) or in the presence of 0.005 or $0.4 \mathrm{mg} \mathrm{mL}^{-1}$ of $\mathrm{Fe}_{3} \mathrm{O}_{4}$ and $\mathrm{Fe}_{3} \mathrm{O}_{4} @$ Arg. Later, the samples were assayed for remaining activity at $450 \mathrm{~nm}$ at appropriate time intervals up to $64 \mathrm{~h}$. Upon determination of inactivation constants $\left(k_{\mathrm{in}}\right)$ in the linear range of activity loss graphs, the half-life $\left(t_{1 / 2}\right)$ of HEWL at each of the incubation conditions was also determined using the following equation: $:^{30}$

$$
t_{1 / 2}=\frac{\ln 2}{k_{\text {in }}}
$$

\section{Results and discussion}

\section{Synthesis and characterization of MNPs}

Currently, because of the biocompatibility and distinctive magnetic properties of iron oxide NPs, they are known as the most common agents for theranostic applications. However, their interaction with proteins is not well understood, which is quite important from the design safety and application points of view. The NPs, $\mathrm{Fe}_{3} \mathrm{O}_{4}$ and $\mathrm{Fe}_{3} \mathrm{O}_{4} @ \mathrm{Arg}$, were synthesized and then characterized using a set of complementary methods, including spectrometry, magnetometry, diffraction, scattering, and microscopy. FT-IR spectra provide a direct proof of the synthesis of $\mathrm{Fe}_{3} \mathrm{O}_{4}$ and $\mathrm{Fe}_{3} \mathrm{O}_{4} @ A r g$ (Fig. 1a). The $\mathrm{Fe}-\mathrm{O}$ characteristic peak of NPs appears at about $561 \mathrm{~cm}^{-1}$. In aqueous medium, the surface of the NPs is modified by OH groups, due to coordination of unsaturated surface Fe atoms with hydroxyl ions or water molecules. These $\mathrm{OH}$ groups absorb IR radiation at about $1633 \mathrm{~cm}^{-1}$ and $3400 \mathrm{~cm}^{-1}$, which bring about deforming and stretching vibrations, respectively. ${ }^{29}$ In Arg coated NPs $\left(\mathrm{Fe}_{3}-\right.$ $\mathrm{O}_{4}$ @Arg), the $\mathrm{C}=\mathrm{O}$ and $\mathrm{C}-\mathrm{O}$ stretching vibrations are located at $\sim 1600$ to $\sim 1630 \mathrm{~cm}^{-1}$. The peak at $2970 \mathrm{~cm}^{-1}$ is due to $\mathrm{C}-\mathrm{H}$ stretching vibration; $\mathrm{N}-\mathrm{H}$ stretching vibration overlaps with $\mathrm{O}-\mathrm{H}$ stretching at $3120 \mathrm{~cm}^{-1}$, which indicates that the surface of the $\mathrm{Fe}_{3} \mathrm{O}_{4} @$ Arg was successfully coated with Arg. The bands at 1556, 1622, 1678, 3064 and $3307 \mathrm{~cm}^{-1}$ also confirm the successful
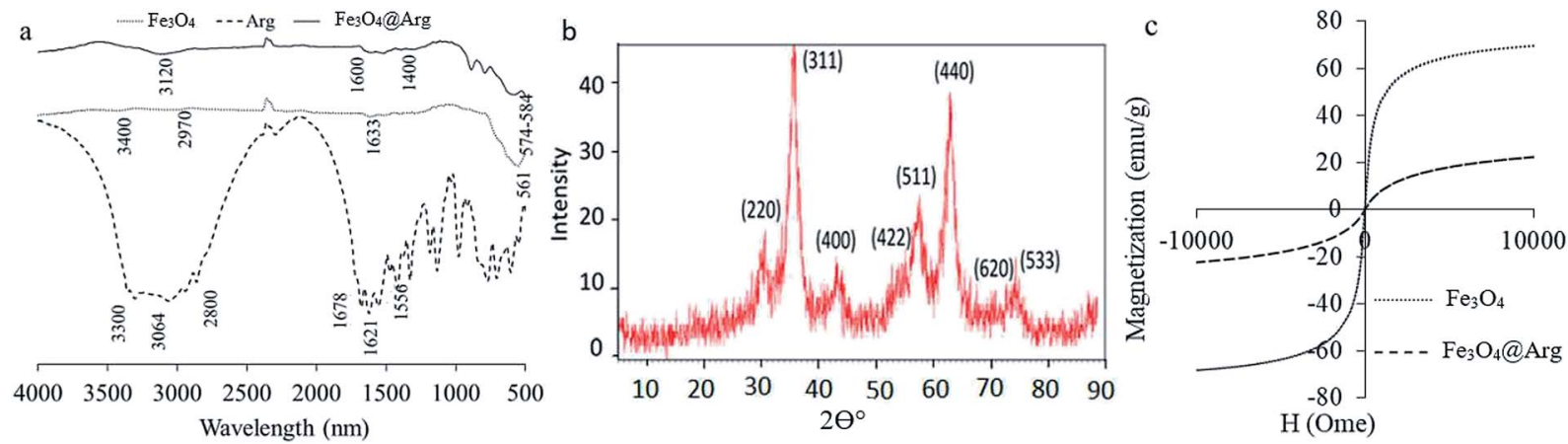

Fig. 1 Characterization of $\mathrm{Fe}_{3} \mathrm{O}_{4}$ and $\mathrm{Fe}_{3} \mathrm{O}_{4}$ @Arg NPs using FT-IR (a), X-ray diffraction (b), and vibrating sample magnetometry (c). 
Table 1 Comparison of the zeta potential and hydrodynamic size of $\mathrm{Fe}_{3} \mathrm{O}_{4}$ and $\mathrm{Fe}_{3} \mathrm{O}_{4}$ @Arg NPs in two conditions as double distilled water (DDW) and phosphate buffer saline (PBS)

\begin{tabular}{|c|c|c|c|c|}
\hline & \multicolumn{2}{|c|}{$\mathrm{DDW}(\mathrm{pH} \leq 7)$} & \multicolumn{2}{|c|}{ PBS $(100 \mathrm{mM}, \mathrm{pH}=7.4)$} \\
\hline & $\zeta(\mathrm{mV})$ & $\begin{array}{l}\text { Size } \\
(d, \mathrm{~nm})\end{array}$ & $\zeta(\mathrm{mV})$ & $\begin{array}{l}\text { Size } \\
(d, \mathrm{~nm})\end{array}$ \\
\hline $\mathrm{Fe}_{3} \mathrm{O}_{4}$ & -29 & 75 & -33.6 & 76 \\
\hline $\mathrm{Fe}_{3} \mathrm{O}_{4} @ A r g$ & 32.2 & 48 & 34.3 & 48 \\
\hline
\end{tabular}

substitution of Arg on NPs. Moreover, $\mathrm{Fe}_{3} \mathrm{O}_{4} @ \mathrm{Arg}$ was characterized using XRD (Fig. 1b). The eight characteristic peak positions were indexed as (220), (311), (400), (422), (511), (440), (620) and (533), which are matched well with the database in the JCPDS International Center for Diffraction Data (JCPDS Card: 190629). The XRD patterns showed the presence of specific diffraction peaks for the synthesized particles, inferring that the NPs were highly crystalline. ${ }^{31}$
VSM was carried out to study the magnetic hysteresis loops of the dried samples (Fig. 1c). Accordingly, both $\mathrm{Fe}_{3} \mathrm{O}_{4}$ and $\mathrm{Fe}_{3} \mathrm{O}_{4}$ @Arg exhibited no hysteresis, with remanence and coercivity being zero, suggesting that the samples are superparamagnetic due to the small size of the NPs (smaller than the critical size). ${ }^{32,33}$ The saturation magnetization values obtained at room temperature were recorded at about 70 and 20 emu g ${ }^{-1}$ for $\mathrm{Fe}_{3} \mathrm{O}_{4}$ and $\mathrm{Fe}_{3} \mathrm{O}_{4} @ A r g$, respectively. The saturation magnetization of $\mathrm{Fe}_{3} \mathrm{O}_{4} @ \mathrm{Arg}$ was lower compared to $\mathrm{Fe}_{3} \mathrm{O}_{4}$ because the Arg is arranged around the $\mathrm{Fe}_{3} \mathrm{O}_{4}$ and prevents the increase in saturation magnetization. This is most probably due to the presence of a non-collinear spin structure at the NPs' interface. ${ }^{34}$ This result confirms the presence of a diamagnetic material (Arg) surrounding the $\mathrm{Fe}_{3} \mathrm{O}_{4}$, which quenches the magnetic moment. ${ }^{35,36}$ However, the strength of the remaining magnetization was enough for an effective magnetic separation to be observed. Thus, $\mathrm{Fe}_{3} \mathrm{O}_{4}$ and $\mathrm{Fe}_{3} \mathrm{O}_{4}$ @Arg NPs exhibit super-paramagnetic properties at room
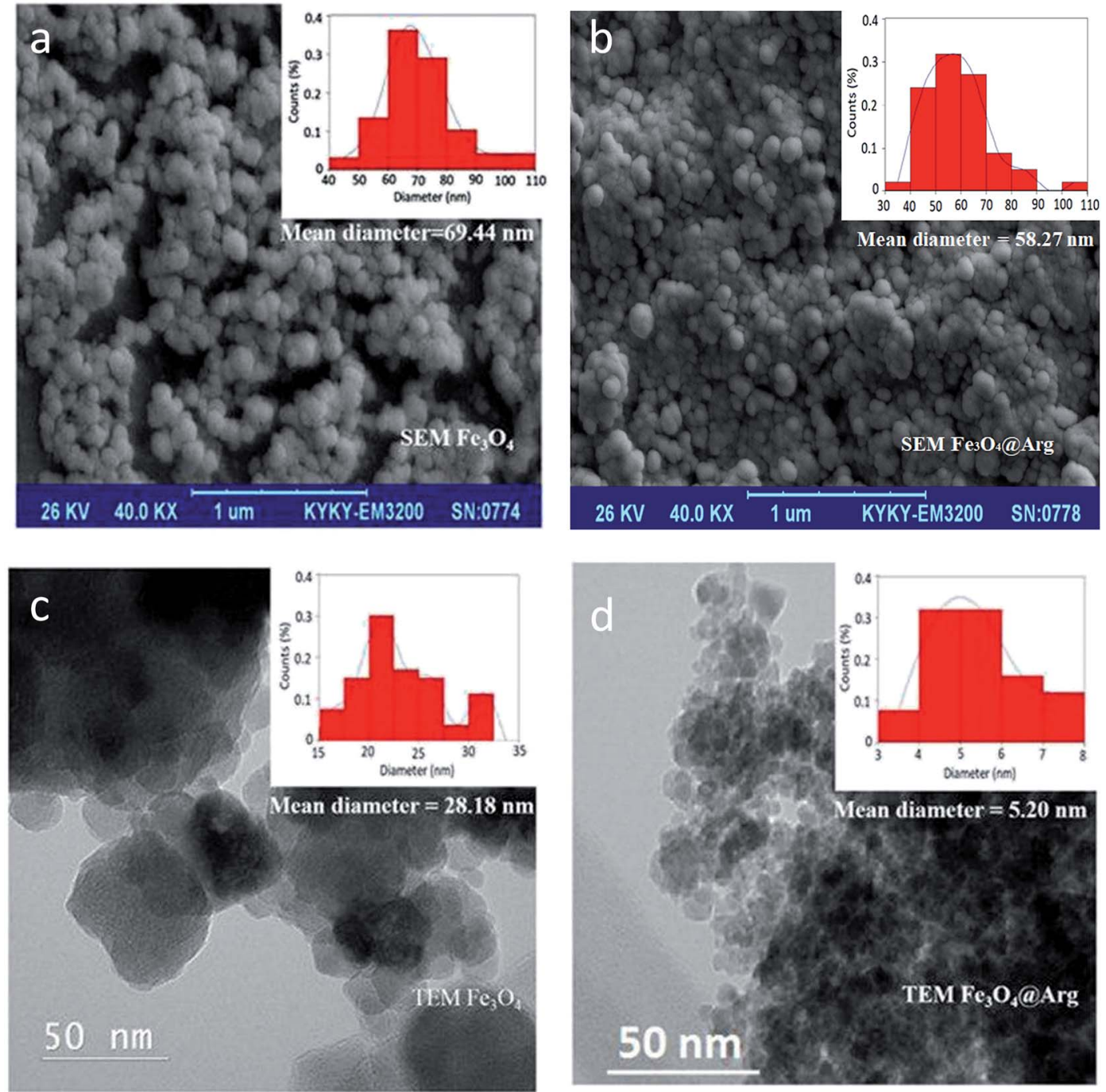

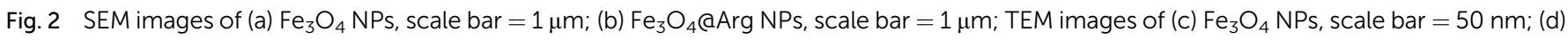
$\mathrm{Fe}_{3} \mathrm{O}_{4} @ \mathrm{Arg} \mathrm{NPs}$, scale bar $=50 \mathrm{~nm}$. Insets reveal the particle size distributions. 
temperature, implying that no remanence remained when the applied magnetic field was removed.

An important factor in protein adsorption is electrostatic interactions. The surface chemistry of biomaterials can influence their performance in biological applications. The electrostatic interaction of the NPs can be controlled through variation of surface charges and can be measured as zeta potential. ${ }^{37}$ In the present study, we determined the zeta potential $(\zeta, \mathrm{mV})$ and hydrodynamic size $(d, \mathrm{~nm})$ of $\mathrm{Fe}_{3} \mathrm{O}_{4}$ and $\mathrm{Fe}_{3} \mathrm{O}_{4} @ A r g$ NPs in two media: at double distilled water $(\mathrm{DDW})(\mathrm{pH} \leq 7)$ and phosphate buffer saline (PBS) $100 \mathrm{mM}$ (pH = 7.4) using DLS (Table 1). Accordingly, all resultant zeta potentials are large enough $(\leq-30)$ to provide a stable colloid dispersion of NPs. Moreover, 3.2 and $0.7 \mathrm{mV}$ increase in the charge magnitudes were observed upon Arg incorporation under both DDW and PBS conditions respectively, while the hydrodynamic sizes were decreased from $\sim 75$ to $48 \mathrm{~nm}$ in both experimental conditions. The presence of guanidine groups of Arg with basic $\mathrm{p} K_{\mathrm{a}}$ ( $c a$. 12.48), probably causes the observed decrease in $\zeta$ potential magnitude for $\mathrm{Fe}_{3} \mathrm{O}_{4}$ @Arg. Fig. 2 shows the electron microscopy (TEM and SEM) images of the $\mathrm{Fe}_{3} \mathrm{O}_{4}$ and $\mathrm{Fe}_{3} \mathrm{O}_{4} @ A$ arg to verify their appearance and size. In accordance with DLS data, the size of the MNPs decreases upon Arg incorporation.

Moreover, the Arg content of the as-synthesized $\mathrm{Fe}_{3} \mathrm{O}_{4} @ A r g$ NPs was estimated to be $1.62 \mu \mathrm{g}$ per $\mathrm{mg}$ of $\mathrm{Fe}_{3} \mathrm{O}_{4}$ @Arg NPs through quantification of amino groups on the surface of NPs using 9,10-phenanthrenequinone based on a fluorescence method (please see Materials and methods section).
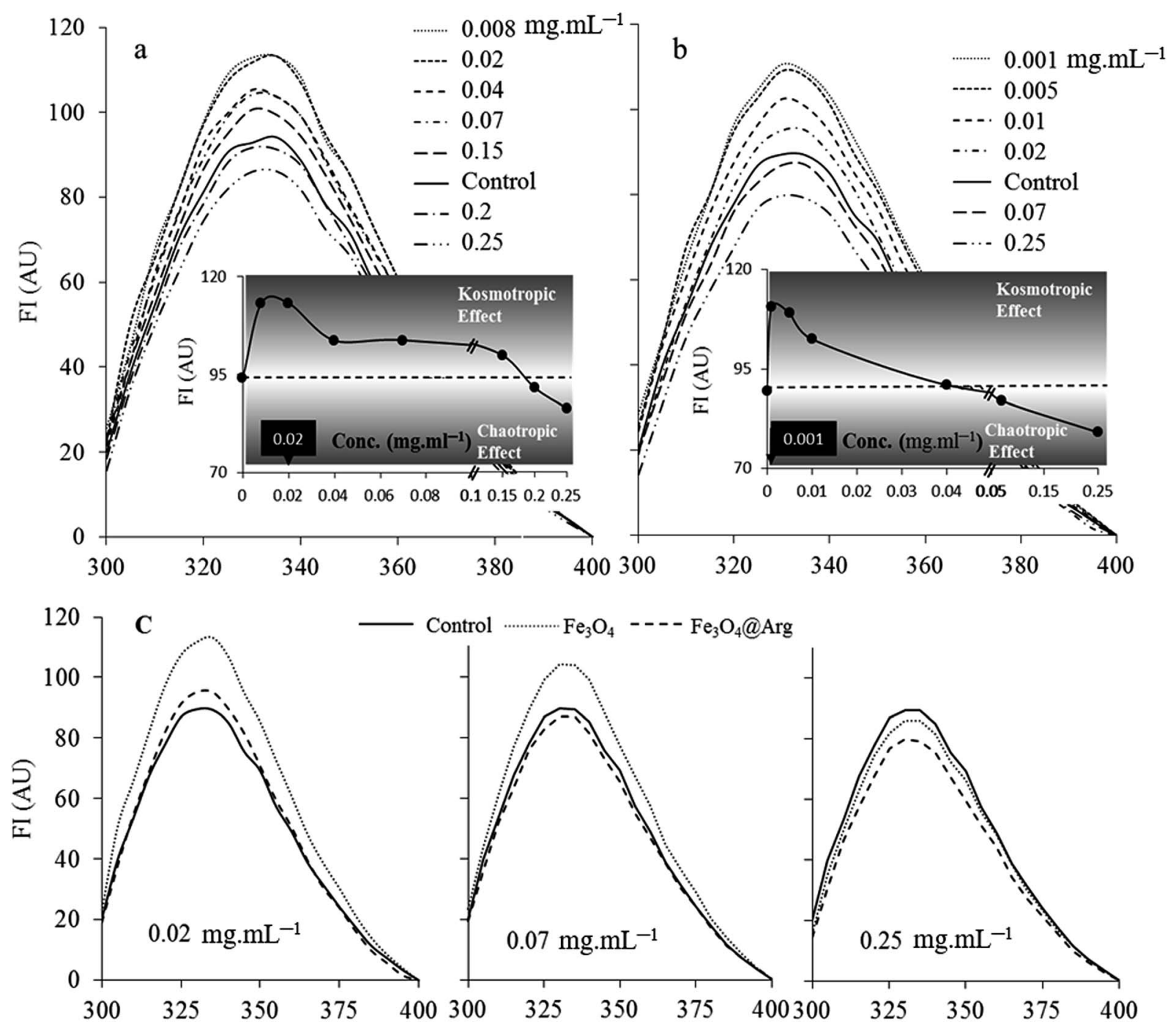

Wavelength (nm)

Fig. 3 Dual concentration dependent (DCD) effects of $\mathrm{Fe}_{3} \mathrm{O}_{4}(\mathrm{a})$ and $\mathrm{Fe}_{3} \mathrm{O}_{4}$ @Arg (b) on the intrinsic fluorescence of $0.2 \mathrm{mg} \mathrm{mL}^{-1}$ lysozyme. Inset to (a) and (b) show the fluorescence intensities as the function of NPs concentration. (c) The comparative intrinsic fluorescence spectra of the lysozyme in the presence low, middle and high concentrations of $\mathrm{Fe}_{3} \mathrm{O}_{4}$ and $\mathrm{Fe}_{3} \mathrm{O}_{4} @ \mathrm{Arg} \mathrm{NPs}$. Each reported data is the average of three experiments. 


\section{The effect of MNPs on HEWL structure and stability}

Tryptophan fluorescence spectroscopy was used to study the structural changes in HEWL at the tertiary level induced by $\mathrm{Fe}_{3} \mathrm{O}_{4}$ or $\mathrm{Fe}_{3} \mathrm{O}_{4} @ A r g$ NPs (Fig. 3). HEWL contains six tryptophan (Trp) residues; among them, Trp62 and Trp108 are the most dominant fluorophores. ${ }^{38}$ The intensity of fluorescence emission is determined by the environment of the fluorophores in HEWL. ${ }^{39}$ The Trp quantum yield and therefore fluorescence intensity increases in a hydrophobic protein core environment. On the contrary, the quantum yield of Trp decreases leading to low fluorescence intensity in a polar hydrophilic environment or an environment exposed to solvent. As depicted in Fig. 3, both $\mathrm{Fe}_{3} \mathrm{O}_{4}$ and $\mathrm{Fe}_{3} \mathrm{O}_{4}$ @Arg NPs show a dual concentration dependent (DCD) effect on Trp fluorescence emission of HEWL, including increased and decreased quantum yield (leading to fluorescence intensity) at low and high concentrations, respectively. The concentration threshold shifts between contrary effects were determined at $0.18 \mathrm{mg} \mathrm{mL}^{-1}(12.86 \mathrm{mg}$ per $\mu \mathrm{mol}$ protein) and $0.05 \mathrm{mg} \mathrm{mL}{ }^{-1}$ (3.6 mg per $\mu \mathrm{mol}$ protein) for $\mathrm{Fe}_{3} \mathrm{O}_{4}$ and $\mathrm{Fe}_{3} \mathrm{O}_{4}$ @Arg, respectively, as the intercepts of the two functions of observed fluorescence intensities in the presence and absence of MNPs. Accordingly, both MNPs were revealed as structure-makers at concentrations lower than the corresponding concentration thresholds; inversely, they were revealed as structure-breakers at concentrations higher than the corresponding concentration thresholds as presented in the insets of Fig. 3. The observed dual dose dependent effects are equivalent to the kosmotropic and chaotropic effects, respectively, which have been reported for co-solvents. Therefore, the maximum kosmotropic-like effects resulted at 0.008 or $0.001 \mathrm{mg} \mathrm{mL}^{-1}$ for $\mathrm{Fe}_{3} \mathrm{O}_{4}$ and $\mathrm{Fe}_{3} \mathrm{O}_{4} @ A r g$, respectively. Moreover, the mentioned quantities (based on Trp quantum yields) are shifted to lower particle concentrations in the presence of Arg, which is a known kosmotropic agent for $\mathrm{Fe}_{3} \mathrm{O}_{4}$ @Arg. As shown in Fig. 3c, both $\mathrm{Fe}_{3} \mathrm{O}_{4}$ and $\mathrm{Fe}_{3} \mathrm{O}_{4} @$ @irg present kosmotropic-like effects on HEWL at $<0.18 \mathrm{mg} \mathrm{mL} \mathrm{m}^{-1}$ and at $<0.05 \mathrm{mg} \mathrm{mL}^{-1}$, respectively. It is evident that they create chaotropic-like effects on HEWL at concentrations higher than $0.18 \mathrm{mg} \mathrm{mL}^{-1}$ and $0.05 \mathrm{mg} \mathrm{mL}^{-1}$, respectively. As a result, it can be said that the structure ordering or disturbing effects of NPs on HEWL are concentration dependent. In the presence of $\mathrm{Fe}_{3} \mathrm{O}_{4} @ A r g$, the localized charge increases on the particle surface, probably due to the effective presence of Arg on the surface of the nanoparticle, making the NPs more prone to exclude from the protein solvent interface to act as a kosmotropic-like agent or to include in the interface to act as a chaotropic-like agent at lower concentrations in comparison with $\mathrm{Fe}_{3} \mathrm{O}_{4}$.

\section{Circular dichroism (CD) spectroscopy}

CD spectroscopy was used to study the secondary structure of HEWL in the absence or presence of $\mathrm{Fe}_{3} \mathrm{O}_{4}$ or $\mathrm{Fe}_{3} \mathrm{O}_{4} @ A r g$ (Fig. 4). Changes in the CD spectra of HEWL (at $0.2 \mathrm{mg} \mathrm{mL}{ }^{-1}$ ) after treatment with $\mathrm{Fe}_{3} \mathrm{O}_{4}$ or $\mathrm{Fe}_{3} \mathrm{O}_{4} @ A r g$ at $0.005 \mathrm{mg} \mathrm{mL}^{-1}$ have resulted from changes in the secondary structure of HEWL due to interaction with NPs in sodium phosphate buffer $(0.1 \mathrm{M}$ and $\mathrm{pH}$ 7.4) after incubation for $1 \mathrm{~h}$.

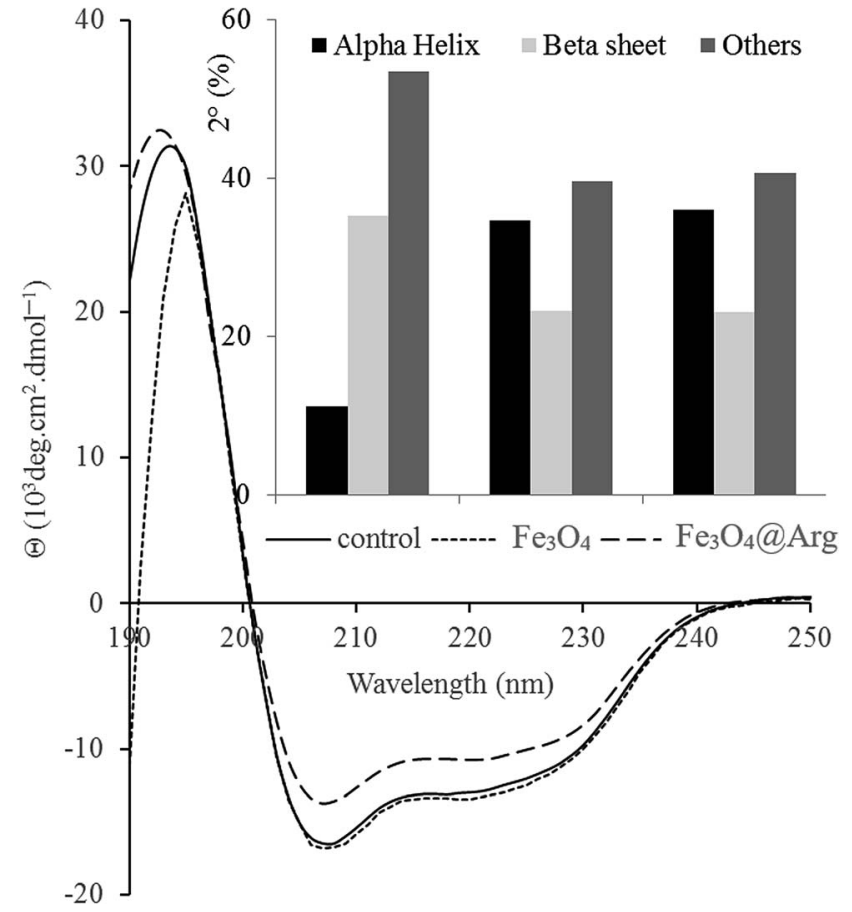

Fig. 4 Far-UV CD spectra of lysozyme after treating with $\mathrm{Fe}_{3} \mathrm{O}_{4}$ or $\mathrm{Fe}_{3} \mathrm{O}_{4} @ \mathrm{Arg} .0 .2 \mathrm{mg} \mathrm{mL}^{-1}$ of lysozyme solution was incubated in the presence and absence of $0.005 \mathrm{mg} \mathrm{mL}^{-1}$ of $\mathrm{Fe}_{3} \mathrm{O}_{4}$ and $\mathrm{Fe}_{3} \mathrm{O}_{4} \mathrm{aArg}$ NPs. Inset to the figure presents the percentage of $\alpha$-helix, $\beta$-sheet and other structural contents after treating with NPs.

The CD spectra of HEWL in the absence of NPs feature characteristic minima at 208 and $220 \mathrm{~nm}$. As depicted in Fig. 4, helicity is significantly increased (and conversely $\beta$-sheet decreased) in the presence of $\mathrm{Fe}_{3} \mathrm{O}_{4}$ or $\mathrm{Fe}_{3} \mathrm{O}_{4}$ @Arg at $0.005 \mathrm{mg} \mathrm{mL}{ }^{-1}$. These data suggest that NPs can exert a structural ordering property under concentration thresholds $\left(0.18 \mathrm{mg} \mathrm{mL}^{-1}\right.$ and $0.05 \mathrm{mg} \mathrm{mL}^{-1}$ for $\mathrm{Fe}_{3} \mathrm{O}_{4}$ and $\mathrm{Fe}_{3} \mathrm{O}_{4} @ \mathrm{Arg}$, respectively), which is in agreement with observed kosmotropic-like properties using spectrofluorimetry (Fig. 4). The effect of NPs on protein secondary structure also depends on the type of NPs in addition to the observed dependency on concentration. Using the same method, it has been reported that $\beta$-sheet content in HEWL in the presence of fullerol NPs drastically increased. ${ }^{40}$ However, it has also been reported that iron oxide NPs have no effect on the secondary structure of HEWL. ${ }^{41}$ Nevertheless, herein, we report that both the type of NPs as well as their concentration should be considered.

\section{Functional stability analysis}

To investigate DCD effects on the functional stability of HEWL as a model protein, enzyme activity was monitored for $64 \mathrm{~h}$ in the absence or presence of NPs at concentrations far lower $\left(0.005 \mathrm{mg} \mathrm{mL}^{-1}\right)$ or far higher $\left(0.4 \mathrm{mg} \mathrm{mL}^{-1}\right)$ than the concentration thresholds $\left(0.18 \mathrm{mg} \mathrm{mL} \mathrm{mL}^{-1}\right.$ and $0.05 \mathrm{mg} \mathrm{mL}^{-1}$ for $\mathrm{Fe}_{3} \mathrm{O}_{4}$ and $\mathrm{Fe}_{3} \mathrm{O}_{4} @ A$ arg, respectively) at $25{ }^{\circ} \mathrm{C}$ (Fig. 5). The functional stability of the enzyme was improved at low concentrations (in the kosmotropic-like range of NP concentration), while drastic activity loss was observed at high concentrations of $\mathrm{Fe}_{3} \mathrm{O}_{4}$ or 


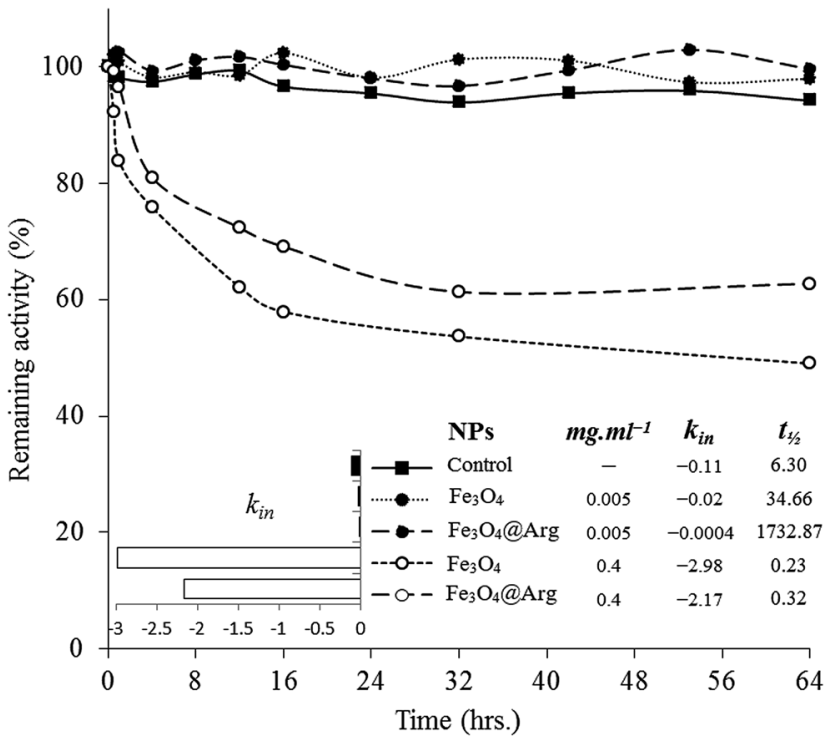

Fig. 5 Evaluation of the remaining lysozyme activity in the presence of $\mathrm{Fe}_{3} \mathrm{O}_{4}$ and $\mathrm{Fe}_{3} \mathrm{O}_{4}$ (aArg NPs at a low $\left(0.005 \mathrm{mg} \mathrm{mL}^{-1}\right)$ and high $\left(0.4 \mathrm{mg} \mathrm{mL}^{-1}\right)$ concentration. Inset to the figure shows the slope of the remaining activities vs. time as an inactivation rate constant $\left(k_{\text {in }}\right)$. Activity was monitored over a $64 \mathrm{~h}$ period.

$\mathrm{Fe}_{3} \mathrm{O}_{4} @$ Arg NPs (in the chaotropic-like range of NP concentration). As depicted in the table included in Fig. 5 , in the presence of $\mathrm{Fe}_{3} \mathrm{O}_{4} @ \mathrm{Arg}$, the inactivation rate constant $\left(k_{\text {in }}\right)$ is effectively lower than that for $\mathrm{Fe}_{3} \mathrm{O}_{4}$. Similarly, the half-lives were also improved on using a lower concentration of NPs. The extent of $t_{1 / 2}$ improvements in the presence of the kosmotropic-like concentration range of $\mathrm{Fe}_{3} \mathrm{O}_{4} @ \mathrm{Arg}$ was 275- and 50-fold higher than the control (absence of NPs) and $\mathrm{Fe}_{3} \mathrm{O}_{4}$, respectively. This indicated that the obtained functional analysis data are in good agreement with the structural evidence and confirm the structure-making kosmotropic-like effect at low concentrations and the structure-breaking chaotropic-like effect at high concentrations of the investigated NPs in HEWL. However, the incorporated co-presence of Arg, a well-known kosmotropic small molecule, with the NP could effectively improve the structure ordering effects of $\mathrm{Fe}_{3} \mathrm{O}_{4}$. It should be noted that the mechanism of the impact of protein stability under interaction with NPs is poorly understood. ${ }^{42}$ Protein structural features and consequently their stabilizing interactions are determined by the water structure and dynamics in their vicinity more prominently than by internal and hydration waters, which are affected by the co-presence of NPs with the protein. It is assumed that proteins are adsorbed on NPs to form a protein corona. ${ }^{43,44}$ Since HEWL is a strongly basic protein with an isoelectric point (pI) of $10.7,{ }^{45}$ the positively charged enzyme, at neutral $\mathrm{pH}$, effectively adsorbs the negatively charged $\mathrm{Fe}_{3} \mathrm{O}_{4}$ or $\mathrm{Fe}_{3} \mathrm{O}_{4} @ A r g$ NPs (Fig. 1c). Protein adsorption on NPs changes the protein hydration pattern, which, in turn, results in protein structure and activity alterations. At far higher ratios of NP/ protein, corona formation occurs to a higher extent and NPs are well saturated by proteins, which, in turn, cooperatively bring about protein hydration and a positive effect on the protein structure. By decreasing the ratio of NP/protein, NPs become partially saturated, resulting in the decrease in protein hydration. Finally, at far lower NP/protein ratios, most of the NPs are not decorated by protein corona, which indicates that hydrated NPs preferentially interfere with protein hydration,

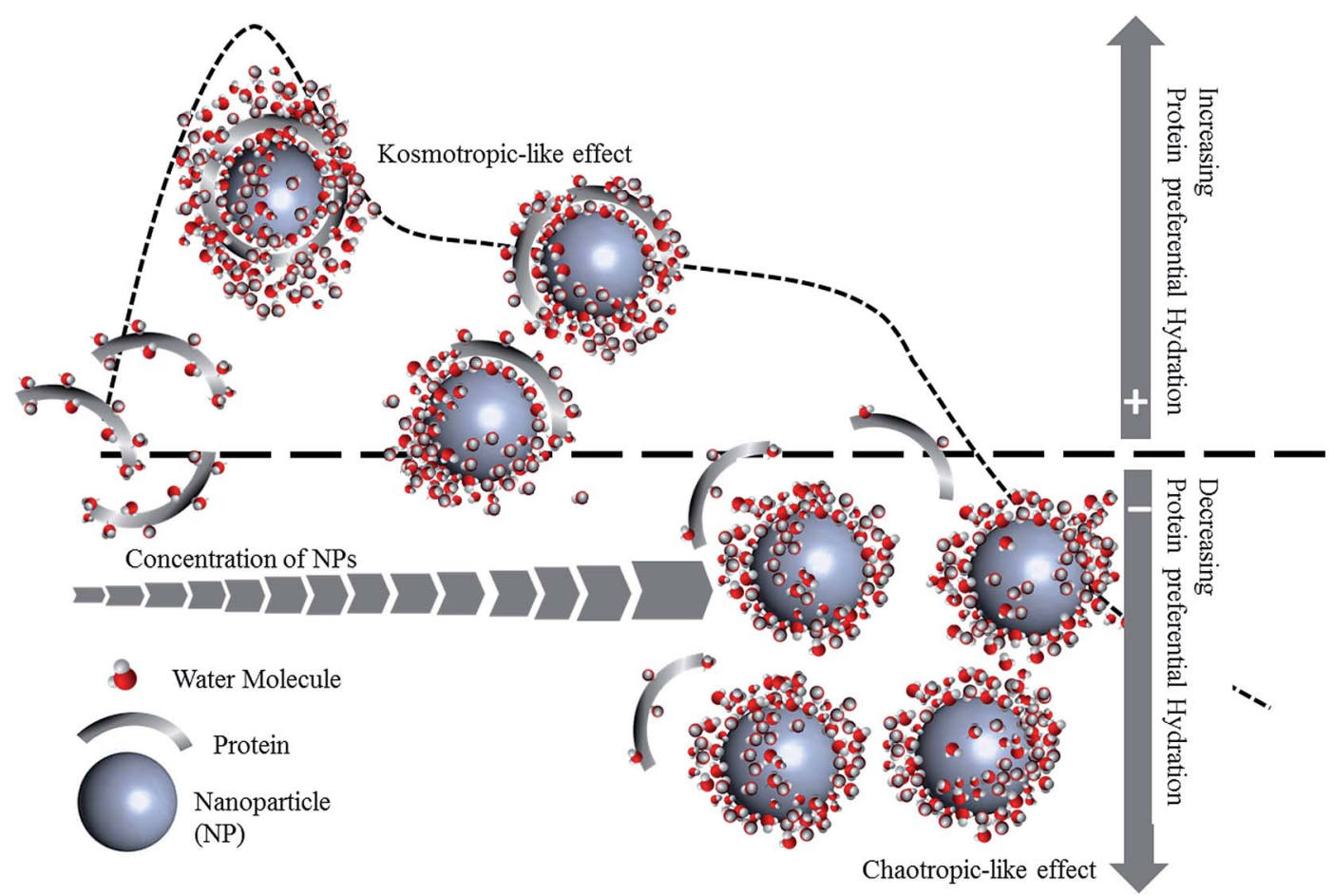

Fig. 6 A hypothetical mechanism of the protein preferential hydration, followed by protein stability modulation by DCD effect of NPs. 
thus negatively affecting protein structure. This hypothetical scenario is summarized in Fig. 6. The NPs influence the structure and biochemical equilibrium in aqueous solutions of proteins, acting indirectly through the structure and dynamics of the hydration water shell that surrounds the protein molecules. At lower NP/protein ratios, the kosmotropic-like effect demonstrated by NPs most probably occurs by enhancing preferential protein hydration and stabilizing the folded state of the proteins. According to our proposed model summarized in Fig. 6, at lower NP/protein ratios the NP surface is well saturated by HEWL corona, which not only provides stabilizing adsorptive interactions through binding with residues but also exclude NPs from preferential hydration, making HEWL more ordered due to improved hydration as a kosmotropic-like effect. At higher $\mathrm{NP} /$ protein ratios the uncovered NPs surfaces are exposed to the solvent, allowing them to interfere in protein hydration and exerting a disordering effect on protein as a chaotropic like effect. In summary, the NPs investigated herein are polar with a negatively charged surface decorated by protein corona, which stabilize HEWL at low concentrations; at high concentrations, they are well hydrated and destabilize HEWL making them a "double-edged sword". However, by incorporation of the amino acid Arg, the maximum kosmotropic-like effect is shifted to the lower concentrations.

\section{Conclusion}

With respect to the emphatic increase in the applications of iron oxide NPs in theranostics, herein, we shed light on the effect of NPs on proteins (from a nano-biosafety point of view) by answering the following question: "How is a model protein, HEWL, affected by NPs?" Results from this research show that NPs either act as stabilizers or destabilizers on HEWL depending on their DCD effects. This has led to a proposed mechanism about the concentration dependency effects of NPs on proteins; NPs indirectly affect the structure and dynamics of the hydration water shells that surround proteins, which in turn influence the structure and function of proteins in a concentration dependent manner. Therefore, NPs provide improved protein hydration at low concentrations, resulting in a kosmotropic-like effect. On the contrary, NPs at higher concentrations adversely interfere with the protein hydration and reveal a chaotropic-like effect. Nevertheless, the mechanism has not yet been fully understood and remains to be further explored.

\section{Conflicts of interest}

The authors declare that they have no conflict of interest with the contents of this article.

\section{Abbreviations}

$\begin{array}{ll}\text { NPs } & \text { Nanoparticles } \\ \text { MNPs } & \text { Magnetic nanoparticles }\left(\mathrm{Fe}_{3} \mathrm{O}_{4} \text { and }\right. \\ & \left.\mathrm{Fe}_{3} \mathrm{O}_{4} @ A r g\right) \\ \text { Arg } & \text { Arginine }\end{array}$

$\begin{array}{ll}\text { M. luteus } & \text { Micrococcus luteus } \\ \text { DCD effect } & \text { Dual concentration dependent effect } \\ \text { HEWL } & \text { Hen egg white lysozyme } \\ \text { FT-IR } & \text { Fourier transform infrared } \\ \text { TEM } & \text { Transmission electron microscopy } \\ \text { SEM } & \text { Scanning electron microscopy } \\ \text { VSM } & \text { Vibrating sample magnetometry } \\ \text { DLS } & \text { Dynamic light scattering } \\ \text { XRD } & \text { X-ray diffraction } \\ \text { CD } & \text { Circular dichroism spectroscopies }\end{array}$

spectroscopies

\section{Acknowledgements}

The supports of the University of Tehran, Center of Excellence in Nanobiomedicine (NBM) and National Institute for Medical Research and Development (NIMAD) are gratefully acknowledged.

\section{Notes and references}

1 L. Fei and S. Perrett, Effect of nanoparticles on protein folding and fibrillogenesis, Int. J. Mol. Sci., 2009, 10, 646-655.

2 M. Mahmoudi, H. R. Kalhor, S. Laurent and I. Lynch, Protein fibrillation and nanoparticle interactions: opportunities and challenges, Nanoscale, 2013, 5, 2570-2588.

3 S. R. Saptarshi, A. Duschl, A. L. Lopata, A. Duschl and A. L. Lopata, Interaction of nanoparticles with proteins: relation to bio-reactivity of the nanoparticle, $J$. Nanobiotechnol., 2013, 11, 26.

4 T. Yokomizo, J. Higo and M. Nakasako, Patterns and networks of hydrogen-bonds in the hydration structure of human lysozyme, Chem. Phys. Lett., 2005, 410, 31-35.

5 D. Russo, G. Hura and T. Head-Gordon, Hydration dynamics near a model protein surface, Biophys. J., 2004, 86, 18521862.

$6 \mathrm{M}$. Tarek and D. J. Tobias, The dynamics of protein hydration water: a quantitative comparison of molecular dynamics simulations and neutron-scattering experiments, Biophys. J., 2000, 79, 3244-3257.

7 N. T. Hunt, L. Kattner, R. P. Shanks and K. Wynne, The dynamics of water-protein interaction studied by ultrafast optical Kerr-effect spectroscopy, J. Am. Chem. Soc., 2007, 129, 3168-3172.

8 U. Heugen, G. Schwaab, E. Bründermann, M. Heyden, X. Yu, D. M. Leitner and M. Havenith, Solute-induced retardation of water dynamics probed directly by terahertz spectroscopy, Proc. Natl. Acad. Sci. U. S. A., 2006, 103, 12301-12306.

9 H. S. Frank and M. W. Evans, Free volume and entropy in condensed systems III. Entropy in binary liquid mixtures; partial molal entropy in dilute solutions; structure and thermodynamics in aqueous electrolytes, J. Chem. Phys., 1945, 13, 507-532.

10 P. L. Privalov and S. J. Gill, Stability of protein structure and hydrophobic interaction, Adv. Protein Chem., 1988, 39, 191234. 
11 P. H. K. De Jong, J. E. Wilson, G. W. Neilson and A. D. Buckingham, Hydrophobic hydration of methane, Mol. Phys., 1997, 91, 99-104.

12 R. M. Murphy and A. M. Tsai, Misbehaving proteins: Protein (mis) folding, aggregation, and stability, Springer Science \& Business Media, 2007.

13 C. P. Schneider, D. Shukla and B. L. Trout, Arginine and the hofmeister series: The role of ion-ion interactions in protein aggregation suppression, J. Phys. Chem. B, 2011, 115, 74477458.

14 T. Arakawa, D. Ejima, K. Tsumoto, N. Obeyama, Y. Tanaka, Y. Kita and S. N. Timasheff, Suppression of protein interactions by arginine: a proposed mechanism of the arginine effects, Biophys. Chem., 2007, 127, 1-8.

15 N. Inoue, E. Takai, T. Arakawa and K. Shiraki, Specific decrease in solution viscosity of antibodies by arginine for therapeutic formulations, Mol. Pharm., 2014, 11, 1889-1896.

16 S. Chakraborti, T. Chatterjee, P. Joshi, A. Poddar, B. Bhattacharyya, S. P. Singh, V. Gupta and P. Chakrabarti, Structure and activity of lysozyme on binding to $\mathrm{ZnO}$ nanoparticles, Langmuir, 2010, 26, 3506-3513.

17 A. Cao, D. Hu and L. Lai, Formation of amyloid fibrils from fully reduced hen egg white lysozyme, Protein Sci., 2004, 13, 319-324.

18 A. A. Vertegel, R. W. Siegel and J. S. Dordick, Silica nanoparticle size influences the structure and enzymatic activity of adsorbed lysozyme, Langmuir, 2004, 20, 6800-6807.

19 A. Ebrahiminezhad, Y. Ghasemi, S. Rasoul-Amini, J. Barar and S. Davaran, Impact of amino-acid coating on the synthesis and characteristics of iron-oxide nanoparticles (IONs), Bull. Korean Chem. Soc., 2012, 33, 3957-3962.

20 Y. Lai, W. Yin, J. Liu, R. Xi and J. Zhan, One-pot green synthesis and bioapplication of l-arginine-capped superparamagnetic $\mathrm{Fe}_{3} \mathrm{O}_{4}$ nanoparticles, Nanoscale Res. Lett., 2010, 5, 302-307.

21 M. Moros, B. Pelaz, P. López-Larrubia, M. L. García-Martin, V. Grazú and J. M. de la Fuente, Engineering biofunctional magnetic nanoparticles for biotechnological applications, Nanoscale, 2010, 2, 1746-1755.

22 L. Stevens, Egg white proteins, Comp. Biochem. Physiol., Part B: Biochem. Mol. Biol., 1991, 100, 1-9.

23 Z. Liu, B. García-Díaz, B. Catacchio, E. Chiancone and H. J. Vogel, Protecting Gram-negative bacterial cell envelopes from human lysozyme: Interactions with Ivy inhibitor proteins from Escherichia coli and Pseudomonas aeruginosa, Biochim. Biophys. Acta, Biomembr., 2015, 1848, 3032-3046.

24 A. L. Morel, S. I. Nikitenko, K. Gionnet, A. Wattiaux, J. LaiKee-Him, C. Labrugere, B. Chevalier, G. Deleris, C. Petibois, A. Brisson and M. Simonoff, Sonochemical Approach to the Synthesis of $\mathrm{Fe}_{3} \mathrm{O}_{4} @ \mathrm{SiO}_{2}$ Core-Shell Nanoparticles with Tunable Properties, ACS Nano, 2008, 2, 847-856.

25 P. I. Girginova, A. L. Daniel-da-Silva, C. B. Lopes, P. Figueira, M. Otero, V. S. Amaral, E. Pereira and T. Trindade, Silica coated magnetite particles for magnetic removal of $\mathrm{Hg}^{2+}$ from water, J. Colloid Interface Sci., 2010, 345, 234-240.
26 N. Graf, D. R. Bielenberg, N. Kolishetti, C. Muus, J. Banyard, O. C. Farokhzad and S. J. Lippard, $\alpha v \beta 3$ integrin-targeted PLGA-PEG nanoparticles for enhanced anti-tumor efficacy of a Pt(Iv) prodrug, ACS Nano, 2012, 6, 4530-4539.

27 https://pubchem.ncbi.nlm.nih.gov/compound/ phenanthrene\#section=Flash-Point.

28 R. E. Smith and R. MacQuarrie, A sensitive fluorometric method for the determination of arginine using 9,10phenanthrenequinone, Anal. Biochem., 1978, 90, 246-255.

29 K. C. Aune and C. Tanford, Thermodynamics of the Denaturation of Lysozyme by Guanidine Hydrochloride. I. Dependence on $\mathrm{pH}$ at $25^{\circ}$, Biochemistry, 1969, 8, 4579-4585.

30 D. Shugar, The measurement of lysozyme activity and the ultra-violet inactivation of lysozyme, Biochim. Biophys. Acta, 1952, 8, 302-309.

31 A. Demortière, P. Panissod, B. P. Pichon, G. Pourroy, D. Guillon, B. Donnio and S. Bégin-Colin, Size-dependent properties of magnetic iron oxide nanocrystals, Nanoscale, 2011, 3, 225-232.

32 S. Laurent, D. Forge, M. Port, A. Roch and C. Robic, Magnetic iron oxide nanoparticles: synthesis, stabilization, vectorization, physicochemical characterizations, and biological applications, Chem. Rev., 2008, 108, 2064-2110.

33 P. Pradhan, J. Giri, G. Samanta, H. D. Sarma, K. P. Mishra, J. Bellare, R. Banerjee and D. Bahadur, Comparative evaluation of heating ability and biocompatibility of different ferrite-based magnetic fluids for hyperthermia application, J. Biomed. Mater. Res., Part B, 2007, 81, 12-22.

34 R. F. Evans, R. W. Chantrell and O. Chubykalo-Fesenko, Surface and interface effects in magnetic core-shell nanoparticles, MRS Bull., 2013, 38, 909-914.

35 R. K. Singh, T. H. Kim, K. D. Patel, J. C. Knowles and H. W. Kim, Biocompatible magnetite nanoparticles with varying silica-coating layer for use in biomedicine: Physicochemical and magnetic properties, and cellular compatibility, J. Biomed. Mater. Res., Part A, 2012, 100, 1734-1742.

36 J. Qu, G. Liu, Y. Wang and R. Hong, Preparation of $\mathrm{Fe}_{3} \mathrm{O}_{4}-$ chitosan nanoparticles used for hyperthermia, Adv. Powder Technol., 2010, 21, 461-467.

37 S. Patil, A. Sandberg, E. Heckert, W. Self and S. Seal, Protein adsorption and cellular uptake of cerium oxide nanoparticles as a function of zeta potential, Biomaterials, 2007, 28, 4600-4607.

38 T. Imoto, L. S. Forster, J. a. Rupley and F. Tanaka, Fluorescence of lysozyme: emissions from tryptophan residues 62 and 108 and energy migration, Proc. Natl. Acad. Sci. U. S. A., 1972, 69, 1151-1155.

39 C. Amara, N. Eghbal, N. Oulahal and P. Degraeve, Properties of lysozyme/sodium alginate complexes for the development of antimicrobial films, Food Res., 2016, 89, 272-280.

40 P. Chen, S. A. Seabrook, V. C. Epa, K. Kurabayashi, A. S. Barnard, D. a. Winkler, J. K. Kirby and P. C. Ke, Contrasting Effects of Nanoparticle Binding on Protein Denaturation, J. Phys. Chem. C, 2014, 118, 22069-22078.

41 Z. Aghili, S. Taheri, H. A. Zeinabad, L. Pishkar, A. A. Saboury, A. Rahimi and M. Falahati, Investigating the interaction of 
Fe nanoparticles with lysozyme by biophysical and molecular docking studies, PLoS One, 2016, 11, e0164878.

42 I. Lynch and K. A. Dawson, Protein-nanoparticle interactions, Nano Today, 2008, 3, 40-47.

43 P. Del Pino, B. Pelaz, Q. Zhang, P. Maffre, G. U. Nienhaus, W. J. Parak, P. del Pino and P. D. U. Nienhaus, Protein corona formation around nanoparticles - from the past to the future, Mater. Horiz., 2014, 1, 301-313.
44 M. Mahmoudi, M. a. Shokrgozar, S. Sardari, M. K. Moghadam, H. Vali, S. Laurent and P. Stroeve, Irreversible changes in protein conformation due to interaction with superparamagnetic iron oxide nanoparticles, Nanoscale, 2011, 3, 1127-1138.

45 Bioactive Egg Compounds, ed. R. Huopalahti, R. LópezFandiño, M. Anton and R. Schade, Springer Berlin Heidelberg, Berlin, Heidelberg, 2007. 